\title{
Port Catheterization: Our Clinical Experience with 156 Diseases
}

\section{Port Kateterizasyonu: 156 Hastalık Klinik Deneyimimiz}

\section{(D) Edip Gönüllüi¹, (D) Serdar Yeşiltaş², (D) Doğan Koca³, (D) Abdurrahman Aycan4, (D) Erkan Doğan5}

${ }^{1}$ Bakırçay University Çiğli Training and Research Hospital, Clinic of Algology, İzmir, Turkey

${ }^{2}$ Bezmialem Vakıf University Faculty of Medicine, Department of Anesthesia and Reanimation, İstanbul, Turkey

${ }^{3}$ Medical Park Hospital, Clinic of Medical Oncology, Kocaeli, Turkey

4Yüzüncü Yıl University Faculty of Medicine, Department of Neurosurgery, İstanbul, Turkey

5 Yüzüncü Yıl University Faculty of Medicine, Department of Medical Oncology, İstanbul, Turkey

\section{Abstract}

Objective: Port catheterization, which can be practically applied by various clinical and surgical branches in our country, is an extremely comfortable procedure in patient groups requiring long-term parenteral treatment, especially malignancy patients.

Method: In this study, 156 patients who underwent port catheterization by an anesthesiologist after the approval of the local ethics committee were evaluated retrospectively.

Results: The procedure was performed in $98.1 \%$ of the patients due to malignancy (originated esophagus: $37.3 \%$, stomach: $24.8 \%$ ). The most common application part was the right internal jugular vein $(65.4 \%)$. Sixty-two patients required two or more punctures. Port was removed due to port pocket infection in $1.9 \%$ of the patients.

Conclusion: In this study, we presented our port catheterization experience and aimed to contribute to the national literature.

Keywords: Anesthesia, complication, malignancy, port

\section{Öz}

Amaç: Ülkemizde pratikte çeşitli klinik ve cerrahi branşlar tarafından uygulanabilen port kateterizasyonu, malignite hastaları başta olmak üzere uzun süreli parenteral tedavi gerektiren hasta gruplarında son derece konforlu bir işlemdir.

Yöntem: Bu çalışmada yerel etik kurul onayı alındıktan sonra anestezi uzmanı tarafından port kateterizasyon uygulanmış olan 156 hasta retrospektif olarak değerlendirildi.

Bulgular: Hastaların \%98,1'ine malignite (özofagus Ca: \%37,3, mide: \%24,8) nedeni ile işlem uygulandı. En sık uygulama yeri sağ internal juguler vendi $(\% 65,4)$. Altmış iki hastada 2 veya daha fazla ponksiyon gerekti. Hastaların \%1,9'unda port cebi enfeksiyonu nedeni ile port çıkarıldı.

Sonuç: Biz bu çalışmada port kateterizasyon deneyimimizi sunduk ve ulusal literatüre katkı sunmayı amaçladık.

Anahtar kelimeler: Anestezi, komplikasyon, malignite, port

\section{Introduction}

Port catheter applications are permanent vascular access applications that allow the administration of long-term, intermittent treatments for intravenous chemotherapy, long-term daily antiviral and antibiotic treatments, and parenteral nutrition (1-3). The ports have a reservoir placed in a pocket that opens into the subcutaneous tissue and a catheter that enters the santal vein through a tunnel opened under the skin and connected to this reservoir, and can be placed in the chest, arms, thighs and, abdomen depending on the vein that was catheterized (2). Early and late complications may occur during the insertion or use of port catheters, which provide great convenience for cancer patients $(4,5)$.

Port procedures in various hospitals in our country are common interests of anesthesiologists, general surgeons, 
thoracic surgeons, pediatric surgeons, radiologists, and cardiovascular surgeons; however, there is no final consensus on this issue (1). In this study, we aimed to present our clinical experience regarding our port catheter applications in a hospital in eastern Turkey and to contribute to the literature.

\section{Materials and Methods}

In this study, patients who were planned for long-term chemotherapy and parenteral nutrition between April 2012 and August 2013 in the Medical Oncology Clinic of Van Regional Training and Research Hospital and who were placed a total implantable port by an anesthesiologist were evaluated retrospectively after the approval of the local ethics committee, dated 19.06.2015 and numbered 2015/4.

All patients were informed about both the intervention to be performed and the complications before the procedure. The mass, infection, and previously received radiotherapy conditions in the intervention area were recorded. While the operation was planned under local anesthesia in all patients who were conscious and could tolerate the procedure, intravenous sedation was applied to patients with anxiety and cooperation disorder. Intravenous ceftriaxone was routinely administered to all patients one hour before the procedure. The patients' heart rhythm, peripheral oxygen saturation $\left(\mathrm{SpO}_{2}\right)$, and non-invasive blood pressure were monitored in the operating room. Those with oxygen saturation below $94 \%$ were given $2-3 \mathrm{Lt} / \mathrm{min}_{2}$. For venous port catheter implantation, local antisepsis was provided to patients, $1 \%$ lidocaine (Jetokain Simplex ${ }^{\circledR}$ amp, Adeka, İstanbul, Turkey) infiltration was applied to the puncture site and port pocket area of all patients. Puncture was performed by using the Seldinger technique after turning the patient's head slightly to the opposite direction when internal jugular vein (IJV) was used.

In this technique, the neck veins were expected to fill in the patient lying on their back. Patients whose veins collapsed during inspiration were taken to the $15-20^{\circ}$ Trendelenburg position. Afterwards, the sternal and clavicular head of the sternocleidomastoid muscle and the clavicula bone were determined. The current triangle is located above the center of the IJV. Catheterization was performed at the apex of the existing triangle with a large 8-inch catheter. While the finger was held to feel the artery slightly, the puncture was performed at a 30-40 degree angle and directed towards the nipple on the same side. Upon the detection of the vein, the injector was removed and a one $\mathrm{cm}$ incision was performed, in which the guidewire would be in the middle, and the vein dilator and sheath were advanced over the guidewire with circular movements. The vascular dilator and guidewire were removed, the mouth of the sheath was closed, and the catheter was advanced through the sheath according to the length of the catheter. Then, the sheath was split in two and peeled off by pulling it up and out. A 2-3 $\mathrm{cm}$ incision was performed ensuring that port pocket was on the second rib, and a subcutaneous pocket was created in accordance with the reservoir dimensions by blunt dissection from the incision caudal. After washing the port reservoir with 100 $\mathrm{u} / \mathrm{mL}$ heparinized liquid, it was locked by connecting with the catheter. The process took about 30 minutes from skin cleansing to suturing.

In patients who underwent femoral vein and subclavian catheterization, preparation and procedures after reaching the venous path were the same as for IJV catheterization. The subclavian vein (SV) extends behind the clavicle over the first rib, towards the anterior scalene muscle insertion. For puncture, the midpoint of the clavicle and the sternal notch were determined first, and the needle was inserted into the skin $1 \mathrm{~cm}$ below the midpoint of the clavicle. The needle was then held in the horizontal plane and advanced towards the back of the clavicle with the tip towards the sternal notch.

For femoral vein catheterization, the femoral artery, $1-2 \mathrm{~cm}$ below the inguinal ligament, was palpated and the needle was inserted $1 \mathrm{~cm}$ medial to where the femoral artery was palpated. Puncture was achieved by advancing the needle upwards and inwards at an angle of 20-30 degrees with the skin.

A port with a Braun ${ }^{\circledast}$ brand (Germany) titanium reservoir body with a single lumen, "Huber" needle was used in all patients. The ports consisted of a reservoir body with a single lumen attached to the catheter, while the intravascular catheter part was made of silicone and polyurethane like other central venous catheters. After the intervention, posterior anterior chest radiography was taken to check the port catheter location and to detect possible hemopneumothorax, and the patients were called for control examination one week after the procedure.

The hospital records of the patients were inspected for their demographic data, primary diagnosis, port placement indication, anesthesia method applied during the procedure, location of the procedure, problems related to the intervention, technique used, complications developed during and after the intervention related to the port, and the reasons for removal of the port. 
Patients who had abnormal bleeding diathesis and thrombocyte count less than $50,000 / \mathrm{mm}^{3}$ and who did not consent were excluded from the study.

\section{Statistical Analysis}

SPSS 15.0 for Windows program will be used for statistical analysis. Descriptive statistics will be given as frequency tables and cross tables for categorical variables, and as mean, median, standard deviation, minimum and maximum for numerical variables.

\section{Results}

Of the 156 patients included in the study, 95 (60.9\%) were male and 61 (39.1\%) were female. The patients were in the age range of 38-87 (median 67) years. Port catheterization was applied to 153 of the patients (98.1\%) since long-term chemotherapy was planned due to malignancy, and to 3 of the patients (1.9\%) due to long-term parenteral nutrition. Of the malignancy patients, 57 (37.3\%) were esophagus, whereas the 38 (24.8\%) were stomach, 22 (14.4\%) colon, 13 (8.5\%) head and neck, 9 (5.9\%) pancreas, 8 (5.2\%) breast, other $6(3.9 \%)$ were solid and hematological malignancies.

Port catheterization was not successful in a single attempt in 62 patients, requiring 2 or more attempts. The procedure was performed through the right IJV in $102(65.4 \%)$ patients, the left IJV in 20 (12.8\%) patients, the right SV in 31 (19.9\%) patients, and the femoral vein in 3 (1.9\%) patients. Ultrasonography-guided IJV procedure was performed in one of the patients due to failure despite multiple attempts. Catheterization was performed through the right femoral vein in 3 patients whose all trials were unsuccessful, and the chamber was placed in the right lower-middle quadrant of the abdomen. One of these patients was an obese patient with a short, thick neck. One of the patients who had a port inserted by femoral vein catheterization was a patient in whom the guidewire could not be advanced despite blood coming from the vascular puncture after multiple trials. In the subsequent Doppler ultrasonography of this patient, thrombosis was observed in the superior vena cava including both the right and left SVs.

During the patient follow-up, 3 ports and port pockets were removed due to infection. The first of these was removed one month after the port was inserted and Staphylococcus aureus grew in the culture taken. The second port was removed 3 months after insertion, and Coagulase negative staphylococcus grew in the culture. The third port was removed 6 months after insertion and Candida albicans grew in the culture. Sepsis due to port catheter infection was not developed. One of the cases was treated conservatively, while two cases were treated with tube thoracostomy. Complications such as arteriovenous fistula, dislocation of the catheter, migration of the port reservoir, and extravascular fluid leakage from the catheter, which can be seen after port catheterization, were not observed in our patients. Complications occurring during and after the intervention are shown in Table 1.

\section{Discussion}

Cancer patients require multiple painful intravenous interventions for cytotoxic agents, antibiotics, blood products and nutritional supplements. Port applications have been widely used in oncology since the 1980s to eliminate this concern and provide patient comfort $(6,7)$. In the literature, Schwarz et al. (8) presented a series of 680 cancer patients with port catheter implantation and noted that the port catheter procedure was well tolerated and found comfortable by cancer patients. In the same study, they observed that the port catheter was functional in $90 \%$ of those who survived 1 year and in $70 \%$ of those who survived 4 years (8). Barrios et al. (9) reported that it was safe and advantageous for oncology patients in their series of 218 patients.

In a study conducted in our country, Eldeş et al. (10) presented their port catheter experiences and reported $39.2 \%$ of their patients were women. In this study, port applications were applied by radiology specialists in the interventional radiology unit (10). In our study, the practitioner was an anesthesiologist and $39.1 \%$ of the patients were women. In our study, the indication for patients with ports inserted was malignancy at a rate of $98.9 \%$, similar to the study of Eldeş et al. (10) Indian researchers reported that they most frequently used port catheters for solid organ malignancies with $38 \%$ breast cancer in their study.

Unlike our study, Eldeş et al. (10) used ultrasonography or fluoroscopy for venous catheterization and did not report

Table 1. Complications during and after port catheterization

\begin{tabular}{lll} 
& n & $\%$ \\
\hline Arterial puncture & 7 & 4.5 \\
Pneumothorax & 3 & 1.9 \\
Cardiac dysrhythmia & 4 & 2.6 \\
Port pocket infection & 3 & 1.9 \\
Wound infection & 2 & 1.3 \\
Catheter thrombosis-venous thrombosis & 2 & 1.3 \\
Subcutaneous hematoma & 2 & 1.3 \\
Total & 23 & 14.8 \\
\hline
\end{tabular}


arterial puncture and pneumothorax. In our study, venous catheterization of 62 patients was unsuccessful in the first attempt. Madabhavi et al. (6) reported catheter thrombosis at a rate of $1 \%(\mathrm{n}=1)$, early catheter infection at $4 \%$, and late catheter infection at $4 \%$ in their study. Also, $2 \%$ of catheter displacement was found in their study. Madabhavi et al. (6) administered antibiotics prophylactically to their patients before port application. Barrios reported 1.7\% pneumothorax and $2.6 \%$ venous thrombosis in his study. In the same study, port pocket infection at a rate of $2.2 \%$ was detected and it was reported that such catheters were removed. It was stated that sepsis developed in one of the Barrios's catheter-infected patients (9). In our study, the rates of pneumothorax $(1.9 \%)$ and port pocket infection (1.9\%) were similar to the Barrios' study, and the rate of venous thrombosis (1.3\%) was lower. Our study showed no sepsis development in our patients with catheter infection. Similar to the study of Madabhavi et al. (6) we administered prophylactic antibiotics to all patients before the procedure. Our findings regarding the complication rates show that the use of imaging methods will decrease the complication rates such as arterial puncture and pneumothorax and increase the comfort of the procedure.

\section{Conclusion}

We presented a limited series of patients in which port catheter application, ensuring comfort in the treatment of patients by providing long-term venous vascular access, was applied by an anesthesiologist in our center. We believe that increasing the experience of using ultrasonography in clinics other than radiology during some clinical situations and procedures will decrease the number of interventions and complications.

\section{Ethics}

Ethics Committee Approval: In this study, patients who were planned for long-term chemotherapy and parenteral nutrition between April 2012 and August 2013 in the Medical Oncology Clinic of Van Regional Training and Research Hospital and who were placed a total implantable port by an anesthesiologist were evaluated retrospectively after the approval of the local ethics committee, dated 19.06.2015 and numbered 2015/4.

Informed Consent: All patients were informed about both the intervention to be performed and the complications before the procedure.
Peer-review: Externally peer-reviewed.

\section{Authorship Contributions}

Concept: E.G., A.A., Design: E.G., A.A., Data Collection or Processing: E.G., D.K, E.D., A.A., Analysis or Interpretation: E.G., S.Y., E.D., Drafting Manuscript: E.G., S.Y., Critical Revision of Manuscript: E.D., D.K., A.A., Final Approval and Accountability: E.G., S.Y., D.K., A.A., E.D.

Conflict of Interest: No conflict of interest was declared by the authors.

Financial Disclosure: The author declared that this study has received no financial support.

\section{References}

1. Özer $\mathrm{AB}$, Bayar $\mathrm{MK}$. İmplante edilebilir venöz port kateter uygulamalarımızın incelenmesi. Fırat Tıp Dergisi 2011;16(1):6-10.

2. Kutlu R. Geçici / kalıcı venöz kateterler ve port yerleştirme. Trd Sem 2015;3(2):298-315.

3. Biffi R, De Braud F, Orsi F, Pozzi S, Arnaldi P, Goldhirsch A, et al. A randomized, prospective trial of central venous ports connected to standard open-ended or Groshong catheters in adult oncology patients. Cancer 2001;92:1204-1212.

4. Ballarini C, Intra M, Pisani Ceretti A, Cordovana A, Pagani M, Farina G, et al. Complications of subcutaneous infusion port in the general oncology population. Oncology 1999;56(2):97-102.

5. Collier PE, Blocker SH, Graff DM, Doyle P. Cardiac tamponade from central venous catheters. Am J Surg 1998;176(2):212-214.

6. Madabhavi I, PatelA, Sarkar M, Anand A, Panchal H, Parikh S. Astudy of use of "PORT" catheter in patients with cancer: a single-center experience. Clin Med Insights Oncol 2017;11:1179554917691031. doi: $10.1177 / 1179554917691031$.

7. Gyves J, Ensminger W, Niederhuber J, Liepman M, Cozzi E, Doan $\mathrm{K}$, et al. Totally implanted system for intravenous chemotherapy in patients with cancer. Am J Med 1982;73(6):841-845.

8. Schwarz RE, Groeger J, Coit DG. Subcutaneously implanted central venous access devices in cancer patients: a prospective analysis. Cancer 1997;79(8):1635-1640.

9. Barrios CH, Zuke JE, Blaes B. Evaluation of an implantable venous access system in a general oncology population. Oncology 1992;49(6):474-478.

10. Eldeş T, Akmangit İ, Dede D, Yıldırım N, Sayın B, Polattaş P. Erişkin hastalarda 498 deri alti port kateter uygulamalari ve komplikasyonlarinin retrospektif değerlendirilmesi. Pam Tıp Derg 2019;12(2):209-214 